\title{
Pengaruh Model Pembelajaran Berbasis Masalah Berbantuan Peta Konsep Terhadap Kompetensi Pengetahuan IPS
}

\author{
*I Dewa Gede Diana Putra1, I Wayan Darsana², Made Putra ${ }^{3}$ \\ ${ }_{123}$ Pendidikan Guru Sekolah Dasar, Fakultas Ilmu Pendidikan, Universitas Pendidikan Ganesha Singaraja, Indonesia
}

\author{
A R T I C L E I N F O \\ Article history: \\ Received 10 May 2019 \\ Received in revised form \\ 10 June 2019 \\ Accepted 15 July 2019 \\ Available online 30 August \\ 2019 \\ Kata Kunci: \\ berbasis masalah, peta \\ konsep. \\ Keywords: \\ problem based, concept \\ map.
}

\begin{abstract}
A B S T R A K
Adapun hasil observasi dimana kompetensi pengetahuan IPS siswa masih kurang. Penelitian ini bertujuan untuk mengetahui perbedaan yang signifikan kompetensi pengetahuan IPS antara kelompok siswa yang dibelajarkan melalui model pembelajaran berbasis masalah berbantuan peta konsep dengan kelompok siswa yang dibelajarkan melalui pembelajaan konvensional siswa kelas IV SD. Jenis penelitian ini adalah eksperimen semu dengan rancangan nonequivalent control group design. Populasi penelitian ini adalah seluruh siswa kelas IV yang berjumlah 134 orang siswa. Sampel penelitian adalah kelas IV SD sebagai kelompok eksperimen sebanyak 32 orang dan kelompok kontrol sebanyak 31 orang yang diperoleh dengan teknik random sampling. Pengumpulan data menggunakan metode tes dengan bentuk tes objektif pilihan ganda biasa. Data analisis menggunakan uji-t (polled varians). Hasil penelitian menunjukkan thitung $=4,014$ sedangkan pada taraf signifikansi $5 \%$ dan $\mathrm{dk}=32+31-2=61$ diperoleh nilai tabel $=2,000$ sehingga thitung $=4,014>$ tabel $=2,000$. Hal ini berarti terdapat perbedaan
\end{abstract} yang signifikan kompetensi pengetahuan IPS antara kelompok siswa yang dibelajarkan dengan model pembelajaran berbasis masalah berbantuan peta konsep dan kelompok siswa yang dibelajarkan dengan pembelajaan konvensional siswa kelas IV SD. Sehingga dapat disimpulkan terdapat pengaruh model pembelajaran berbasis masalah berbantuan peta konsep terhadap kompetensi pengetahuan IPS siswa kelas IV SD.

\begin{abstract}
A B S T R A C T
The aimed of this research was to know the significant differences of IPS knowledge competence between a group of students studied by using model problem based learning assisted concept map with a group of students who studied by using convensional model of fourth grade students of $S D$ Gugus VII Ubud district in 2017/2018. This research wass quasi experimental by using non-equivalent control group design. The population of this research were all of fourth grade student of SD Gugus VII Ubud district in 2017/208 amounted 134 students of 5 class. The sample of this research were students of IV SD N. 4 Sayan as an experimental group amounted 32 students and students of IV SD $N 5$ Sayan as a control group amounted 31 students, has got by using the technic of random sampling. The data collected by using the multiple choice method. The data analized by using t-test (polled varians). Result of this research shows that $t_{\text {count }}$ is 4,014, mean while the significant value is $5 \%$ and $d k$ is 50 , the $t_{\text {tabel }}$ is 2,000 , so $t_{\text {count }} 4,014>t_{\text {tabel }} 2,000$. It means that there is a significant difference of IPS knowledge competence between a group students studied by using model problem based learning assisted concept map with a group students studied by using convensional model of fourth grade students of SD Gugus VII Ubud district in 2017/2018. So it can conclude that there is a significant effect of model problem based learning assisted concept map of IPS knowledge competence of fourth grade students SD Gugus VII Ubud district in 2017/2018.
\end{abstract}

Copyright () Universitas Pendidikan Ganesha. All rights reserved. 


\section{Pendahuluan}

Pendidikan adalah hal terpenting bagi setiap negara untuk dapat berkembang pesat. Negara yang hebat akan menempatkan pendidikan sebagai prioritas pertamanya, karena dengan pendidikan, kemiskinan pada rakyat di negara tersebut akan dapat tergantikan menjadi kesejahteraan. Bagaimanapun, dalam perkembangannya, pendidikan di Indonesia senantiasa harus menghadapi beberapa masalah di setiap tahapnya. Masalahmasalah tersebut hanya dapat diselesaikan dengan partisipasi dari semua pihak yang terkait di dalam sistem pendidikan, seperti orangtua, guru-guru, kepala sekolah, masyarakat, dan juga peserta didik itu sendiri. Pada fase input, orangtua memiliki kontribusi besar dalam memperkenalkan nilai-nilai baik kepada anak-anak mereka. Orangtua bertanggung jawab penuh untuk mendidik anak-anak mereka dengan nilai-nilai kepemimpinan, sehingga mereka mempunyai bekal yang cukup untuk menjadi cikal bakal pemimpin ketika mereka mulai memasuki institusi formal, seperti sekolah. Pada fase proses, orangtua bekerjasama dengan para guru dan kepala sekolah untuk memberikan penguatan kepada peserta didik dalam menerapkan nilai-nilai kepempinan yang baik melalui budaya organisasi di sekolah. Terakhir, pada tahap output, peserta didik harus menghadapi begitu banyak tantangan di dunia nyata, di luar sekolah. Peserta didik yang sudah melalui tahap-tahap sebelumnya di sekolah dengan budaya organisasi yang mengajarkan dan membiasakan nilai-nilai baik dalam hidupnya, maka akan tumbuh menjadi pemimpin yang hebat untuk negara ini mr(Megawati, 2012).

Pendidikan di SD merupakan hal yang sangat penting karena sebagai dasar bagi pendidikan selanjutnya. Pendidikan dasar diselenggarakan untuk memberikan dasar pengetahuan, sikap dan keterampilan. Pendidikan dasar inilah yang selanjutnya dikembangkan untuk meningkatkan kualitas diri siswa. Dalam Undang-Undang Nomor 20 Tahun 2003, tentang Sistem Pendidikan Nasional, pendidikan diartikan sebagai usaha sadar dan terencana untuk mewujudkan suasana belajar dan proses pembelajaran agar peserta didik secara aktif mengembangkan potensi dirinya untuk memiliki kekuatan spiritual keagamaan, pengendalian diri, kepribadian, kecerdasan, akhlak mulia, serta keterampilan yang diperlukan dirinya, masyarakat, bangsa, dan negara(Sugiyono, 2015a). Pembukaan Undang-Undang Dasar Negara Republik Indonesia Tahun 1945 menyatakan bahwa tujuan nasional bangsa Indonesia tercantum dalam alenia keempat yakni "melindungi segenap bangsa Indonesia dan seluruh tumpah darah Indonesia dan untuk memajukan kesejahteraan umum, mencerdaskan kehidupan bangsa, dan ikut melaksanakan ketertiban dunia yang berdasarkan kemerdekaan, perdamaian abadi, dan keadilan sosial" (Permendikbud Nomor 104, 2014). Untuk mencapai tujuan tersebut pendidikan harus didesain sedemikian rupa agar siswa mampu untuk berkreasi dalam menemukan pengetahuannya sendiri. Agar dapat mewujudkan tujuan pendidikan nasional maka disusunlah sebuah rencana tertulis yang dikenal dengan kurikulum.

"Kurikulum adalah seperangkat rencana dan pengaturan mengenai tujuan, isi, dan bahan pelajaran serta cara yang digunakan sebagai pedoman penyelenggaraan kegiatan pembelajaran untuk mencapai tujuan pendidikan tertentu" (Permendikbud Nomor 104, 2014). "Kurikulum 2013 bertujuan untuk mempersiapkan manusia Indonesia agar memiliki kemampuan hidup sebagai pribadi dan warga negara yang beriman, produktif, kreatif, inovatif, dan afektif serta mampu berkontribusi pada kehidupan bermasyarakat, berbangsa, bernegara, dan peradaban dunia" .Di dalam kurikulum 2013, ada beberapa aspek yang dintakan dalam kompetensi inti salah satunya adalah kompetensi pengetahuan. Adanya kurikulum, proses pembelajaran menjadi lebih terencana dan teratur. Pembelajaran merupakan upaya guru untuk membantu siswa melakukan kegiatan belajar. Terciptanya suasana kelas yang menyenangkan maka siswa menjadi lebih aktif dalam proses pembelajaran. Proses pembelajaran tersebut harus diterapkan pada semua mata pelajaran termasuk IPS. (Susanto, 2013) menyatakan IPS memiliki tujuan utama adalah "untuk mengembangkan potensi peserta didik agar peka terhadap masalah sosial yang terjadi di masyarakat, memiliki sikap mental positif terhadap perbaikan segala ketimpangan yang terjadi, dan terampil mengatasi setiap masalah yang terjadi sehari hari baik yang menimpa dirinya sendiri maupun masyarakat." Menurut Zubaedi (2011:289) tujuan pembelajaran IPS mencangkup empat hal. Pertama, mengembangkan pengetahuan kesosiologian, kegeografian, keekonomian, kesejahteraan,dan kewarganegaraan (atau konsep-konsep berkaitan dengan kehidupan dan lingkungan ).

Pembelajaran berbasis masalah (problem based learning) merupakan salah satu model pembelajaran yang berasosiasi dengan pembelajaran kontekstual. Pembelajaran berbasis masalah memberi pengertian bahwa dalam pembelajaran siswa dihadapkan pada suatu masalah, yang kemudian diharapkan melalui pemecahan masalah siswa belajar keterampilan-keterampilan berpikir yang lebih mendasar. Model pembelajaran inidibuat oleh ahli pendidikan untuk mencari alternatif pembelajaran yang dianggap mampu membangun situasi pembelajaran agar dapat memberi stimulus dan fokus pada aktivitas berpikir siswa. Lebih lanjut Bound \& Felleti (1998) menyatakan pembelajaran berdasarkan masalah (problem based learning) adalah suatu pendekatan untuk membelajarkan siswa dalam 
mengembangkan keterampilan berfikir dan keterampilan memecahkan masalah, sekaligus melatih kemandirian siswa (Hakim, Noer, \& Gunowibowo, 2014).

Arends (2012) menjelaskan bahwa ada lima tahapan dalam pembelajaran berbasis masalah, yaitu 1) mengenalkan siswa pada masalah; guru menyampaikan tujuan pembelajaran yang hendak dicapai, mengecek apersepsi siswa dengan melakukan tanya jawab materi sebelumnya, dan memberikan motivasi, 2) mengorganisasi siswa untuk belajar; guru mengorganisasi siswa belajar dalam kelompok, 3) membantu investigasi mandiri dan kelompok; guru mendorong siswa untuk mengumpulkan data dan melakukan percobaan, 4) mengembangkan dan mempresentasikan hasil karya; guru memberi kesempatan pada siswa untuk mempresentasikan hasil diskusinya dan membantu dalam kegiatan tukar pendapat, dan 5) menganalisis dan mengevaluasi proses pemecahan masalah; guru membantu siswa menganalisis dan mengevaluasi proses berpikir mereka dalam investigasi dan keterampilan intelektual yang digunakan saat pemecahan masalah dan merefleksi pembelajaran yang telah dilakukan. Saat siswa melakukan investigasi dan menemukan solusi sendiri, siswa dibantu dengan langkah-lang (Sam Nisak, 2015).

Berdasarkan Undang-undang Nomor 20 Tahun 2003 tentang Sistem Pendidikan Nasional, UndangUndang Nomor 14 Tahun 2005 tentang Guru dan Dosen dan peraturan Pemerintah Nomor 19 Tahun 2005 tentang Standar Nasional Pendidikan menyebutkan bahwa guru adalah pendidik profesional. Seorang guru atau pendidik profesional harus memiliki kualifikasi akademik minimum sarjana (S-1) atau diploma empat (D-IV), menguasai kompetensi (pedagogik, profesional, sosial dan kepribadian), memiliki sertifikasi pendidik, sehat jasmani dan rohani, serta memiliki kemampuan untuk mewujudkan tujuan pendidikan nasional. Kompetensi guru diartikan sebagai penguasaan terhadap suatu tugas (mengajar dan mendidik), keterampilan, sikap, dan apresiasi yang diperlukan untuk menunjang keberhasilan proses pembelajaran yang dilakukannya. Dengan demikian, kompetensi yang dimiliki oleh setiap guru akan menunjukkan kualitas guru yang sebenarnya. Kompetensi tersebut akan diwujudkan dalam bentuk penguasaan ketrampilan, pengetahuan maupun sikap profesional dalam menjalankan tugas dan fungsi sebagai guru. . Menurut Glickman dalam Bafadal yang menegaskan bahwa seseorang akan bekerja secara profesioanl bilaman orang tersebut memiliki kemampuan profesional bilamana memiliki kemampuan tinggi dan motivasi kerja tinggi (Fitriani, Murniat, \& Usman, 2017).

Guru adalah suatu sebutan bagi jabatan, posisi, dan profesi bagi seseorang yang mengabdikan dirinya dalam bidang pendidikan melalui interaksi edukatif secara terpola, formal, dan sistematis. Dalam UU R.I. Nomor 14 Tahun 2005 tentang guru dan dosen pada bab I pasal 1 dinyatakan bahwa: Guru adalah pendidik profesional dengan tugas utama mendidik, mengajar, membimbing, mengarahkan, melatih, menilai, dan mengevaluasi peserta didik pada pendidikan anak usia dini jalur pendidikan formal, pendidikan dasar, dan pendidikan menengah. Guru yang profesional akan tercermin dalam penampilan pelaksanaan pengabdian tugas-tugas yang ditandai dengan keahlian, baik dalam materi maupun metode. Di samping keahliannya, sosok guru profesional ditunjukkan melalui tanggung jawabnya dalam melaksanakan seluruh pengabdiannya. Guru profesional hendaknya mampu memikul dan melaksanakan tanggung jawabnya sebagai guru kepada peserta didik, orang tua, masyarakat, bangsa, negara, dan agamanya. Sebagai pengajar atau pendidik, guru merupakan salah satu faktor penentu keberhasilan setiap upaya pendidikan. Itulah sebabnya setiap adanya inovasi pendidikan, khususnya dalam kurikulum dan peningkatan sumber daya manusia yang dihasilkan dari upaya pendidikan, selalu bermuara pada faktor guru. Hal ini menunjukkan bahwa betapa eksisnya peran guru dalam dunia pendidikan. Guru menjadi faktor yang menentukan mutu pendidikan karena guru berhadapan langsung dengan para peserta didik dalam proses pembelajaran di kelas. Di tangan guru, mutu dan kepribadian peserta didik dibentuk. Karena itu, perlu sosok guru kompeten, bertanggung jawab, terampil, dan berdedikasi tinggi. Guru adalah kurikulum berjalan. Sebaik apa kurikulum dan sistem pendidikan yang ada tanpa didukung oleh kemampuan guru, semuanya akan sia-sia. Guru berkompeten dan bertanggung jawab, utamanya dalam mengawal perkembangan peserta didik sampai ke suatu titik maksimal. Tujuan akhir seluruh proses pendampingan guru adalah tumbuhnya pribadi dewasa yang utuh. Seiring dengan Dengan demikian, guru juga harus senantiasa meningkatkan keahliannya dan senantiasa mengikuti perkembangan ilmu pengetahuan dan teknologi sehingga ia mampu menghadapi berbagai tantangan (Shabir, 2015).

"Dengan menguasai konsep, dimungkinkan untuk memperoleh pengetahuan yang tidak terbatas" (Al-Tabany, 2014). Pada pembelajaran dapat menggunakan peta dalam merumuskan konsep-konsep tersebut yang disebut dengan peta konsep. Peta konsep adalah suatu ilustrasi grafis konkret yang mengindikasikan bagaimana suatu konsep tunggal dihubungkan ke konsep lain pada kategori yang sama (Al-Tabany, 2014). "Peta konsep digunakan untuk mengomunikasikan idea-idea dan relasi-relasi yang kompleks dan/atau membuat struktur berpikir peserta didik menjadi lebih sederhana, sehingga mendorong belajar menjadi lebih bermakna" (Yusuf, 2017). Berdasarkan pendapat dari kedua para ahli tersebut, dapat disimpulkan bahwa peta konsep merupakan suatu konsep ilustrasi grafis yang dihubungkan ke konsep lain agar membuat struktur berpikir peserta didik menjadi lebih sederhana. 
Penerapan Model Pembelajaran Berbasis Masalah Berbantuan Peta Konsep bertujuan untuk mengaktifkan struktur kognitif siswa dan pembelajaran akan lebih bermakna. Untuk itu dilakukan penelitian yang berjudul "Pengaruh Model Pembelajaran Berbasis Maslah Berbantuan Peta Konsep Terhadap Kompetensi Pengetahuan IPS Siswa Kelas IV SD Gugus VII Kecamatan Ubud Tahun Pelajaran 2017/2018”.

\section{Metode}

Penelitian ini dilaksanakan di Gugus VII Kecamatan Ubud Tahun Pelajaran 2017/2018. Adapun waktu penelitian ini dilaksanakan pada bulan April sampai bulan Mei 2018. perlakuan sebanyak 6 kali di kelompok eksperimen dan 6 kali di kelompok kontrol. Jumlah perlakuan yang diberikan telah disesuaikan dengan jam pelajaran terkait materi dalam penelitian ini yang telah diatur dalam kurikulum dan silabus. Jenis penelitian yang dilakukan dalam penelitian ini adalah penelitian kuantitatif dengan desain eksperimen yaitu desain quasi eksperiment (Eksperimen Semu). Bentuk desain eksperimen yang digunakan adalah Nonequivalent Control Group Design. Desain ini melibatkan 2 kelas yakni kelas yang mendapatkan perlakuan khusus dengan penerapan Model Pembelajaran Berbasis Masalah Berbantuan Peta Konsep sebagai kelas eksperimen, dan kelas yang menggunakan pembelajaran Konvensional sebagai kelas kontrol. . Rancangan eksperimen semu Nonequivalent Control Group Design diformulasikan sebagai berikut.

\begin{tabular}{|lcc|}
\hline $\mathbf{O}_{1}$ & $\mathbf{X}$ & $\mathbf{O}_{2}$ \\
& $\ldots \ldots \ldots \ldots \ldots \ldots \ldots \ldots \ldots \ldots \ldots \ldots \ldots \ldots \ldots \ldots \ldots \ldots$ \\
$\mathbf{O}_{3}$ & $\mathbf{O}_{4}$ \\
\hline
\end{tabular}

\section{Gambar 1.}

Rancangan Penelitian Nonequivalent Control Group Design

(Sumber: Sugiyono, 2015:116)

Pretest diberikan untuk kelompok kontrol dan kelompok eksperimen. Setelah itu peneliti memberikan perlakuan, yaitu dengan memberikan model pembelajaran berbasis masalah berbantuan peta konsep kepada kelompok eksperimen dan memberikan model pembelajaran konvensional kepada kelompok kontrol. Setelah diberikan perlakuan, dilakukan posttest untuk mengetahui kompetensi pengetahuan IPS.

"Populasi merupakan keseluruhan dari objek, orang, peristiwa, atau sejenisnya yang menjadi perhatian dan kajian dalam penelitian" (Setyosari, 2015). "Populasi adalah wilayah generalisasi yang terdiri atas: objek/subjek yang mempunyai kualitas dan karakteristik tertentu yang ditetapkan oleh peneliti untuk dipelajari dan kemudian ditarik kesimpulannya" (Sugiyono, 2015:117). "Populasi adalah keseluruhan objek dalam suatu penelitian" Agung (2014:69). Jadi dapat disimpulkan pengertian populasi adalah sekelompok orang yang mempunyai karakteristik tertentu yang ingin diteliti untuk dipelajari dan kemudian ditarik kesimpulannya. Populasi dari penelitian ini adalah seluruh siswa kelas IV (empat) SD Gugus VII Kecamatan Ubud Tahun Pelajaran 2017/2018. Jumlah populasi dari penelitian ini adalah 134 orang.

Pada penelitian ini sampel yang digunakan untuk penelitian adalah bagian dari populasi penelitian. "Sampel ialah sebagian dari populasi yang dimbil, yang dianggap mewakili seluruh populasi dan diambil dengan menggunakan teknik tertentu" (Agung, 2014). Dalam penelitian ini sampel terdiri atas dua kelas, yaitu satu kelas eksperimen dan satu kelas kontrol. Teknik yang digunakan untuk mengambil sampel dari populasi disebut teknik sampling. Teknik pengambilan sampel pada penelitian ini adalah Random Sampling yang dirandom kelasnya, sehingga setiap kelas mendapatkan peluang yang sama untuk menjadi sampel penelitian. Pemilihan sampel penelitian ini tidak dilakukannya pengacakan individu melainkan hanya pengacakan kelas. Karena tidak bisa mengubah kelas yang telah terbentuk sebelumnya. Kelas dipilih sebagaimana telah terbentuk tanpa campur tangan peneliti dan tidak dilakukannya pengacakan individu, kemungkinan pengaruh-pengaruh dari keadaan siswa mengetahui dirinya dilibatkan dalam eksperimen dapat dikurangi sehingga penelitian ini benar-benar menggambarkan pengaruh perlakuan yang diberikan.

Cara pengundian kelompok sampel dilakukan dengan menulis masing-masing nama kelas IV di seluruh SD populasi pada kertas kemudian digulung. Gulungan tersebut dimasukkan ke dalam sebuah 
kotak kemudian dikocok. Setelah itu, peneliti mengambil satu gulungan kertas dan mengambil satu gulungan kertas lain tanpa memasukkan kembali gulungan kertas sebelumnya. Nama-nama kelas pada kedua gulungan kertas tersebut merupakan sampel penelitian. Selanjutnya kelas-kelas yang menjadi sampel penelitian tersebut diberikan pretest. Skor dari hasil pretest kelas-kelas tersebut kemudian dianalisis menggunakan uji $t$ untuk penyetaraan kelas. Kemudian peneliti mengadakan pengundian lagi dari dua sampel yang diperoleh untuk menentukan kelompok eksperimen dan kelompok control sehingga dapat ditetapkan kelas IV SD N 4 Sayan sebagai kelas eksperimen dan kelas IV SD N 5 Sayan sebagai kelas kontrol.

"Variabel adalah segala sesuatu yang akan menjadi objek pengamatan dalam penelitian dan jika diukur memiliki variasi" (Setyosari, 2015). Penelitian ini menyelidiki pengaruh variabel bebas yakni model pembelajaran berbasis masalah berbantuan peta konsep terdahap variabel bebas yakni kompetensi pengetahuan IPS siswa. Data yang diperlukan adalah data tentang Kompetensi Pengetahuan IPS siswa kelas IV SD Gugus VII Kecamatan Ubud. Untuk mengumpulkan data Kompetensi Pengetahuan IPS tersebut digunakan metode tes.

\section{Hasil dan Pembahasan}

Data Pada penelitian ini diklasifikasikan menjadi dua yaitu, (1) Kompetensi Pengetahuan IPS siswa kelas IV yang dibelajarkan dengan Model Pembelajaran Berbasis Masalah Berbantuan Peta Konsep, (2) Kompetensi pengetahuan IPS siswa kelas IV yang dibelajarkan dengan pembelajaran konvensional. Deskripsi data kompetensi pengetahuan IPS siswa melalui tabel frekuensi meliputi rerata (mean) dan varians. Berdasarkan perhitungan tersebut diperoleh rerata (mean) kompetensi pengetahuan IPS kelompok eksperimen yaitu 83,28 dan varians yaitu 85,12. Sementara itu berdasarkan perhitungan diperoleh rerata (mean) kompetensi pengetahuan PKn kelompok kontrol yaitu 72,36 dan varians yaitu 151,26 .

Uji prasyarat dilakukan terlebih dahulu sebelum uji hipotesis menggunakan uji-t. Uji prasyarat tersebut meliputi uji normalitas dan uji homogenitas varians. Uji normalitas dilakukan untuk mengetahui sebaran frekuensi skor, untuk menguji data kompetensi pengetahuan PKn kelompok eksperimen dan kontrol adalah rumus Chi Kuadrat. Kriteria pengujian pada uji normalitas adalah jika $\mathrm{X}^{2}$ hitung $<\mathrm{X}^{2}$ tabel maka sebaran data kedua kelompok berdistribusi normal.

Berdasarkan hasil uji normalitas kelompok eksperimen, diperoleh Chi Kuadrat hitung $\left(\mathrm{X}^{2}\right.$ hitung $=$ $4,44)$ kemudian nilai tersebut dibandingkan dengan Chi Kuadrat tabel dengan taraf signifikan 5\% dk 61 ( $\mathrm{X}^{2}$ tabel= 11,07). Hal ini menunjukkan bahwa $\mathrm{X}^{2}$ hitung $<\mathrm{X}^{2}$ tabel berarti data kompetensi pengetahuan IPS kelompok eksperimen berdistribusi normal. Berdasarkan hasil uji normalitas kelompok kontrol, diperoleh Chi Kuadrat hitung $\left(\mathrm{X}^{2}\right.$ hitung $\left.=3,63\right)$ kemudian nilai tersebut dibandingkan dengan Chi Kuadrat tabel (X2tabel= 11,07). Hal ini menunjukkan bahwa $X^{2}$ hitung $<\mathrm{X}^{2}$ tabel berarti data kompetensi pengetahuan PKn kelompok kontrol berdistribusi normal. Uji homogenitas varians dilakukan terhadap data kompetensi pengetahuan PKn antara kelompok eksperimen dan kelompok kontrol. Pengujian homogenitas varian menggunakan uji F pada taraf signifikansi $5 \%(\alpha=0,05)$.

Dari hasil perhitungan diperoleh $\mathrm{F}_{\text {hit }}=1,78$ sedangkan untuk taraf signifikan $5 \% \mathrm{~F}$ tabel dengan $\mathrm{db}$ $(31,30)$ adalah 1,84. Ini Berarti Fhit $<$ Ftabel, $1,16<1,84$ maka data memiliki varians yang homogen. Berdasarkan hasil uji prasyarat yang terdiri dari uji normalitas dan uji homogenitas varians, disimpulkan bahwa data kedua kelompok sampel ialah berdistribusi normal dan memiliki varians yang homogen. Berdasarkan hasil uji normalitas dan homogenitas dapat diketahui bahwa data yang diperoleh dari kelompok eksperimen dan kelompok kontrol berdistribusi normal dan memiliki varians yang homogen. Karena data yang diperoleh telah memenuhi semua prasyarat, uji hipotesis dilakukan dengan

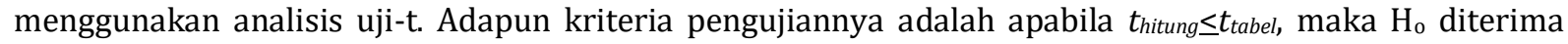
(gagal ditolak) dan $\mathrm{H}_{a}$ ditolak. Dengan $\mathrm{db}=\mathrm{n}_{1}+\mathrm{n}_{2}-2$ dan taraf signifikansi $5 \%(\alpha=0,05)$.

Hasil analisis uji t diperoleh thitung $=4,014$. Harga tersebut kemudian dibandingkan dengan harga $t_{\text {tabel }}$ dengan $\mathrm{dk}=32+31-2=61$ dan taraf signifikansi $5 \%$ sehingga diperoleh harga $t_{\text {tabel }}=2,000$, karena $t_{\text {hitung }}>t_{\text {tabel }} t_{\text {hitung }}=4,014>t_{\text {tabel }}(\alpha=0,05)=2,000$ maka Ho ditolak atau Ha diterima. Hal ini berarti terdapat perbedaan yang signifikan kompetensi pengetahuan IPS antara kelompok siswa yang dibelajarkan melalui Model Pembelajaran Berbasis Masalah Berbantuan Peta Konsep dengan yang dibelajarkan melalui pembelajaran konvensional siswa kelas IV SD Gugus VII Kecamatan Ubud tahun pelajaran 2017/2018.

Perolehan data kompetensi pengetahuan IPS pada kedua kelompok dapat diketahui bahwa kedua kelompok yang awalnya memiliki kemampuan setara, lalu setelah diberikan perlakuan yang berbeda, perolehan data kompetensi pengetahuan IPS mengalami perbedaan. Kompetensi pengetahuan IPS siswa pada kelompok eksperimen lebih baik apabila dibandingkan dengan kompetensi pengetahuan IPS siswa 
pada kelompok kontrol. Hal ini disebabkan oleh pembelajaran yang diterapkan pada kelompok eksperimen memiliki keunggulan. Perbedaan yang signifikan kompetensi pengetahuan IPS antara kelompok eksperimen dengan kelompok kontrol karena perbedaan pemberian perlakuan yang diberikan saat pembelajaran. Kelompok eksperimen diberikan pembelajaran berbasis masalah berbantuan peta konsep memiliki nilai rerata yang lebih tinggi dibandingkan dengan kelompok kontrol yang diterapkan pembelajaran konvensional. Pembelajaran Berbasis Masalah dipadukan dengan peta konsep akan membuat siswa lebih bersemangat dalam proses pembelajaran. Hal itu karena pembelajaran berbasis masalah berbantuan peta konsep menekankan kepada siswa untuk mengaktifkan struktur kognitif siswa dan dapat saling berbagi informasi bersama-sama dengan pasangan yang berbeda dalam waktu singkat secara teratur dalam pelaksanaan pembelajaran. Pembelajaran akan menjadi lebih menyenangkan karena

\section{Simpulan dan Saran}

Dari Berdasarkan pengujian hipotesis dan pembahasan dapat disimpulkan bahwa terdapat perbedaan yang signifikan kompetensi pengetahuan IPS antara kelompok siswa yang dibelajarkan melalui Model Pembelajaran Berbasis Masalah Berbantuan Peta Konsep dengan yang dibelajarkan melalui pembelajaran konvensional siswa kelas IV SD Gugus VII Kecamatan Ubud tahun pelajaran 2017/2018. Hal ini dibuktikan dengan hasil hasil analisis uji-t yaitu thitung $=4,014$ dan dengan taraf signifikan $5 \% \mathrm{dk}=61$ diperoleh ttabel $=2,000$, maka 4,014 $>2,000$. Rerata (mean) kelompok eksperimen yaitu 83,28 dan kelompok control yaitu 72,36. Berdasarkan hasil penelitian ini, maka dapat diajukan beberapa saran sebagai tindak lanjut dari penelitian ini. Saran ini diajukan kepada berbagai kalangan sebagai berikut. (1) Kepada Guru, melihat hasil penelitian pada kompetensi pengetahuan IPS dengan Model Pembelajaran Berbasis Masalah Berbantuan Peta Konsep ini, guru hendaknya menerapkan Model Pembelajaran Berbasis Masalah Berbantuan Peta Konsep dalam pembelajaran di waktu-waktu tertentu. (2) Kepada Lembaga Sekolah, lembaga sekolah disarankan agar dapat menggunakan hasil penelitian ini sebagai pendukung sumber belajar guru dalam meningkatkan kualitas pembelajaran dengan menciptakan pembelajaran yang menyenangkan di sekolah sehingga sekolah mampu menghasilkan siswa yang memiliki output berkualitas. (3) Kepada Peneliti Lain, peneliti lain disarankan agar memanfaatkan hasil penelitian ini sebagai referensi untuk melaksanakan penelitian selanjutnya atau menemukan inovasi kegiatan pembelajaran lainnya yang bermakna bagi siswa.

\section{Daftar Rujukan}

Agung, A. A. G. (2014). Metodologi Penelitian Pendidikan. Malang: Aditya Media Publish.

Al-Tabany, T. I. B. (2014). Mendesain Model Pembelajaran Inovatif, Progresif dan Kontekstual. Jakarta: Prenada Media Grup.

Arends, R. i. (2012). Learning to Teach ninth edition. New York: McGraw-Hill Education (UK).

Bound, \& Felleti. (1998). The Challenge of Problem-Based Learning. Sydney: Koan Page.

Fitriani, C., Murniat, A., \& Usman, N. (2017). Kompetensi Profesional Guru Dalam Pengelolaan Pembelajaran Di Mts Muhammadiyah Banda Aceh. Jurnal Administrasi Pendidikan, 5(2), 88-95.

Hakim, S., Noer, S. H., \& Gunowibowo, P. (2014). Penerapan Model Pembelajaran Berbasis Masalah untuk Meningkatkan Kemampuan Berpikir Kritis dan Disposisi Matematis Siswa. Jurnal Pendidikan Matematika Universitas Lampung, 2(6).

Megawati, P. (2012). Meretas Permasalahan Pendidikan Di Indonesia. Jurnal Formatif, 2(3), 227-234.

Permendikbud Nomor 104. (2014). Penilaian Hasil Belajar Oleh Pendidik Pada Pendidikan Dasar dan Pendidikan Menengah. Jakarta: Permendikbud.

Sam Nisak, H. (2015). Pembelajaran Berbasis Masalah Berdasarkan Langkah-Langkah Polya untuk Meningkatkan Kemampuan Menyelesaikan Soal Cerita Matematika. Jurnal Matematika KreatifInovatif, 6(2), 156-163.

Setyosari. (2015). Metode Penelitian Pendidikan dan Pengembangan. Jakarta: Prenada Media Grup.

Shabir, M. (2015). KEDUDUKAN GURU SEBAGAI PENDIDIK: (Tugas dan Tanggung Jawab, Hak dan Kewajiban, dan Kompetensi Guru). Jurnal Aukaduna, 2(2), 221-232.

Sugiyono. (2015a). Metode Penelitian Pendidikan (Pendekatan Kuantitatif, kualitatif, dan R\&D). Bandung: Alfabeta. 
Sugiyono. (2015b). Metode Penelitian Pendidikan Pendekatan Kuantitatif,Kualitatif, dan R\&D. Bandung: Alfabeta.

Susanto, A. (2013). Teori Belajar dan Pembelajaran di Sekolah Dasar. Jakarta: PRENADAMEDIA GROUP.

Yusuf, M. (2017). Asesmen dan Evaluasi Pendidikan. Jakarta: KENCANA.

Zubaedi. (2011). Desain Pendidikan Karakter: Konsepsi dan Aplikasinya Dalam Lembaga Pendidikan. Jakarta: Kencana Predana Media Group. 